\title{
PENGARUH MODEL PEMBELAJARAN (STAD) STUDENT TEAM ACHIEVEMENT DIVISIONS BERBANTUAN LKS TERHADAP HASIL BELAJAR SISWA KELAS X JASA BOGA PADA MATA AJAR KEAMANAN PANGAN DI SMK PARIWISATA TRIATMA JAYA SINGARAJA
}

\author{
Ni Komang Ayu Novianti, Ni Desak Made Sri Adnyawati, Luh Masdarini \\ Jurusan Pendidikan Kesejahteraan Keluarga, Fakultas Teknik dan Kejuruan \\ Universitas Pendidikan Ganesha \\ Singaraja, Indonesia \\ e-mail : ayu.novi429@gmail.com, adnyawati09@gmail.com, \\ masdarini@undiksha.ac.id
}

\begin{abstract}
Abstrak
Penelitian ini bertujuan untuk mengetahui pengaruh model pembelajaran STAD (Student Team Achivement Divisions) berbantuan LKS terhadap hasil belajar keamanan pangan. Jenis penelitian ini adalah quasi eksperimen dengan desain Nonequivalent Posttest Only Control Group Design. Penelitian ini menggunakan dua kelompok sampel, yaitu kelompok eksperimen dan kelompok kontrol. Kelompok eksperimen dalam penelitian ini adalah kelompok siswa yang mendapatkan pembelajaran dengan model pembelajaran (STAD) Student Team Achievement Divisions berbantuan LKS, sedangkan kelompok kontrol adalah kelompok siswa yang menggunakan model pembelajaran konvensional. Penentuan sampel dalam penelitian ini dilakukan dengan teknik random sampling. Berdasarkan hasil uji hipotesis dengan uji $t$, diperoleh $t_{\text {hitung }}$ adalah 5,36. Sedangkan tabel sebesar 1,67 dengan taraf signifikansi adalah 5\%. Hal ini menunjukkan terdapat pengaruh yang signifikan hasil belajar keamanan pangan siswa yang belajar dengan menggunakan model pembelajaran STAD (Student Team Achievement Divisions) berbantuan LKS dengan siswa yang belajar dengan menggunakan model pembelajaran konvensional pada kelas $X$ Jasa Boga SMK Pariwisata Triatma Jaya Singaraja.
\end{abstract}

Kata Kunci : Hasil Belajar, Model Pembelajaran STAD (Student Team Achievement Divisions), LKS.

\begin{abstract}
Abstrack
This research is aimed at knowing the effect of STAD (Student Team Achievement Divisions) model assisted by stuctured student's worksheet on problem student's learning result in food safety. This type of research is a quasi-experimental desaind whit Nonequivalent Posttest Only Control Group Design. This study used two sample groups, namely the experimental group and the control group. Theexperimental group in this study is a group of in this STAD (Student Team Achievement Divisions) model assisted by stuctured student's worksheet, while the control group is group of students who use conventional learning models. The determination of this study was carried out by random sampling technique. Based on the results of hypothesis testing whit the $t_{\text {test, }}$, it was found to be 5,36 . While the $t_{\text {table }}(0,05)$ is 1,67 with a significance level of $5 \%$. This show that there is a significant influence on the learn by using the STAD (Student Team Achievement Divisions) model assisted by stuctured student's worksheet whit students who learn using conventional learning models in ten grade of culinary Department at Triatma Jaya Tourism Vocational School in Singaraja
\end{abstract}

Keyword : science learning result, STAD (Student Team Achievement Divisions) model, stuctured student's worksheet 


\section{Pendahuluan}

Perkembangan Ilmu Pengetahuan

dan Teknologi (IPTEK) saat ini berkembang dengan sangat pesat sehingga untuk mengatasi hal tersebut dibutuhkan sumber daya manusia (SDM) yang berkualitas dan mampu bersaing. Salah satu upaya untuk meningkatkan kualitas sumber daya manusia (SDM) adalah melalui bidang pendidikan. Kemajuan suatu bangsa dan negara dapat dilihat dari bidang pendidikannya, sehingga apabila pendidikannya berkualitas maka sumber daya manusia yang dihasilkan berkualitas pula. Untuk meningkatkan kualitas dibidang pendidikan maka diperlukan sekolahsekolah yang akan melahirkan SDM (Sumber Daya Manusia) yang berkualitas. Sekolah merupakan tempat peserta didik untuk dapat memperoleh pendidikan. Salah satu lembaga di bidang pendidikan yang mampu melahirkan SDM yang berkualitas dan berkompeten yaitu SMK ( Sekolah Menengah Kejuruan).

SMK merupakan salah satu jenjang pendidikan yang melatih siswa untuk memiliki keterampilan sesuai dengan jurusan yang dipilih agar siswa mampu, trampil, dan diterima di dunia kerja setelah lulus SMK. SMK Pariwisata Triatma Jaya Singaraja yang merupakan lembaga pendidikan pariwisata yang beralamat di daerah kawasan pariwisata Lovina Singaraja yaitu di jalan raya Singaraja-Seririt, Desa Anturan, Buleleng. Bidang keahlian yang dibuka di Sekolah ini yaitu bidang Pariwisata. Bidang pariwisata dibagi menjadi 2 program keahlian yaitu program keahlian Akomodasi Perhotelan dan Jasa Boga.

Program keahlian yang dimiliki SMK Pariwisata Triatma Jaya Singaraja adalah Jasa Boga. Pada program keahlian Jasa Boga terdapat beberapa mata ajar produktif. Salah satu mata ajar produktif tersebut adalah Keamanan Pangan. Keamanan pangan merupakan salah satu program produktif Jasa Boga yang standar kompetensinya harus dicapai oleh setiap siswa. Mata ajar Keamanan pangan diberikan kepada siswa selama 1 tahun untuk 2 semester yaitu semester ganjil dan semester genap dengan 8 kompetensi dasar. Kompetensi dasar yang terdapat di mata ajar Keamanan pangan yaitu (1) Mendeskripsikan sanitasi hygiene, dan keselamatan kerja, (2) Menjelaskan sumber-sumber dan jenisjenis mikroorganisme pengotor terkait dengan struktur, pertumbuhan dan pengaruhnya terhadap kesehatan dan keselamatan, (3) mendeskripsikan prinsip sanitasi hygiene dan keselamtan kerja melalui kebersihan diri dan lingkungan kerja, dan (4) menjelaskan manfaat keamanan pangan di tempat kerja, 5) Mengidentifikasi jenis-jenis bahan pembersih dan bahan saniter, 6) mendeskripsikan keselamatan kerja meliputi kecelakaan kerja, api dan kebakaran, dan alat pelindung kerja, 7) mendeskripsikan kesehatan kerja meliputi persyaratan ruang kerja dan penyakit akibat kerja, dan 8) mendeskripsikan prosedur membersihkan peralatan dan ruangan area kerja.

Berdasarkan hasil observasi pada hari Sabtu, 27 Februari 2018 di SMK Pariwisata Triatmajaya Singaraja kenyataannya dalam kegiatan belajar mengajar pada mata ajar Keamanan pangan hasil ulangan akhir semester kelas $X$ Jasa Boga masih banyak siswa yang mendapatkan nilai dibawah KKM (Kriteria Ketuntasan Minimum) sedangkan KKM yang diterapkan oleh sekolah yaitu 75. Adapun data hasil belajar siswa yang belum tuntas akan dijabarkan melalui tabel berikut.

Tabel 1

Persentase ketuntasan hasil belajar siswa pada mata ajar Keamanan pangan semester semester ganjil dan genap siswa Tahun 2015/2016 dan 2016/2017

\begin{tabular}{ccc}
\hline Tahun & Tuntas & $\begin{array}{c}\text { Tidak } \\
\text { tuntas }\end{array}$ \\
\hline $2015 / 2016$ & $34 \%$ & $66 \%$ \\
$2016 / 2017$ & $42 \%$ & $58 \%$ \\
\hline
\end{tabular}

(Sumber/leger siswa kelas $X$ Jasa Boga SMK Pariwisata Triatma Jaya Singaraja)

Dari tabel di atas dapat dilihat bahwa persentase nilai hasil belajar siswa pada mata pelajaran Keamanan pangan mengalami peningkatan yaitu $8 \%$. Dengan demikian proses belajar mengajar di kelas 
belum mampu untuk meningkatkan nilai siswa. Penyebab utama dari masalah di atas yaitu keterbatasan waktu guru untuk mempersiapkan model pembelajaran. Keterbatasan waktu guru disebabkan oleh banyaknya mata ajar yang dipengang guru dan tugas administrasi yang harus diselesaikan guru pada saat mengajar.

Solusi yang dapat digunakan untuk mengatasi masalah rendahnya hasil belajar siswa adalah dengan model pembelajaran inovatif. Mengingat bahwa pembelajaran Keamanan pangan merupakan salah satu mata ajar yang menekankan siswa lebih memahami konsep teoritis maka dengan demikian salah satu model pembelajaran yang efektif diterapkan untuk mata ajar Keamanan pangan adalah model pembelajaran STAD (Student Team Achievement Divisions).

Pembelajaran STAD (Student

Team Achievemnt Devisions) merupakan salah satu tipe dari model pembelajaran kooperatif dengan menggunakan kelompok-kelompok kecil dengan jumlah kelompok terdiri dari 4-5 orang siswa secara hiterogen. Diawali penyampaian tujuan pembelajaran, penyampaian materi, kegiatan kelompok, kuis dan penghargaan Yasir (2015) dalam Research and Development Journal Od Education volume. 2 No. 1. Menurut Imas Kurniasih (2016:22) model pembelajaran siswa dalam kelas tertentu dipecah menjadi kelompok dengan angota 4-5 orang, terdiri dari laiki-laki dan perempuan, berasal dari berbagai suku, memiliki kemampuan tinggi, sedang dan rendah. Pembelajaran ini memeberikan kesempatan kepada siswa untuk bertanya kepada para teman-temannya, sehingga tidak terlalu terfokus bertanya kepada guru. Model ini diharapkan dapat membantu siswa dalam memecahkan permasalahan dalam pembelajaran melalui kerjasama dengan sesama anggota kelompok. Sehingga terciptanya suasana yang mendorong siswa merasa saling membutuhkan, saling memberikan motivasi untuk meraih hasil belajar yang optimal.

Model pembelajran kooperatif tipe STAD diharapkan dapat menimbulkan suasana belajar yang mengembirakan dan bermakna. Karena pengalaman yang didapat dengan ikut berpartisipasi dalam kelompok kecil dalam pembelajaran sehingga membantu siswa dalam proses pembelajaran ketrampilan, kerjasama tim, dan sekaligus secara bersama mengembangkan sikap demonstrasi dan ketrampilan teknis. Keunggulan pada model pembelajaran STAD (Student Team Achievement Division) adalah siswa dalam suatu lingkungan belajar yang nyaman dan menyenangkan yaitu dalam kelompok sebaya, siswa dapat saling bertukar pendapat, bersama-sama mendiskusikan masalah serta siswa yang satu dapat belajar dari siswa yang lain dalam suatu kelompok dan siswa mendapat penghargaan berupa pujian, skor, hadiah dan sejenisnya. Maka melalui penelitian eksperimen kelas ini akan dicoba untuk menerapkan model pembelajaran STAD (Student Team Achievement Division) dengan tujuan dapat meningkatkan hasil belajar siswa dalam mata ajar keamanan pangan.

Dalam proses pembelajaran, bantuan media pembelajaran memiliki arti cukup penting. Media pembelajaran dapat berfungsi sebagai alat bantu untuk menjelaskan bahan ajar yang tidak dijelaskan guru. Cara penyajian materi pembelajaran dalam LKS meliputi penyampaian materi secara ringkas kegiatan yang melibatkan siswa secara aktif misalnya latihan soal, diskusi dan percobaan sederhana. Seorang guru diharapkan mampu menggunakan media pembelajaran dengan maksimal agar mencapai sasaran dengan target sesuai yang diinginkan dalam kurukulum 2013. LKS merupakan suatu lembar kerja yang dipersiapkan oleh guru untuk mempermudah jalannya diskusi yang dilakukan oleh setiap kelompok. Masingmasing kelompok diberikan LKS yang merupakan panduan atau tugas yang harus dikerjakan oleh setiap kelompok. Dengan demikian proses diskusi kelompok akan lebih menghemat waktu karena bahan diskusi sudah dipersiapkan oleh guru.

Berdasarkan hal tersebut, peneliti merasa terdorong untuk melakukan 
Jurnal Bosaparis: Pendidikan Kesejahteraan Keluarga

Volume 10, Nomor 1, Maret 2019

penelitian dengan judul Pengaruh Model Pembelajaran STAD (Student Team

Achievement Division) berbantuan LKS terhadap Hasil Belajar Siswa Kelas X Jasa Boga pada Mata Ajar Keamanan Pangan di SMK Pariwisata Triatma Jaya Singaraja.

\section{Metode}

Jenis penelitian yang
digunakan dalam penelitian ini adalah penelitian eksperimen. Penelitian ini bersifat Quasi Eksperimental (Eksperimen Semu), karena peneliti tidak mungkin melakukan kontrol terhadap semua variabel selain perlakukan.

Rancangan dalam penelitian ini

yakni Non-equivalent Posttest Only Control Group Design. Pada desain ini terdapat dua kelompok yang masingmasing dipilih secara acak. Kelompok pertama diberi perlakuan (tratment) sedangkan kelompok kedua tidak diberi perlakuan (treatment). Kelompok yang diberi perlakuan disebut kelompok eksperimen dan kelompok yang yang tidak diberi perlakuan disebut kelompok kontrol. Desain penelitian dapat dilihat pada tabel dibawah ini.

Tabel 2

Desain penelitian

"Nonequivalent Posttest Only Control Group Design"

\begin{tabular}{lll}
\hline Kelompok & Perlakuan & Post- test \\
\hline Eksperimen & $\mathrm{X}$ & $\mathrm{O}_{1}$ \\
Kontrol & - & $\mathrm{O}_{2}$ \\
\hline
\end{tabular}

(sumber: dimodifikasi dari sugiyono, 2015:502)

Keterangan :

$\mathrm{E}=$ Kelompok Eksperimen

$\mathrm{K}=$ Kelompok Kontrol

$X$ =Perlakuan Yaitu Penerapan Model Pembelajaran STAD

- $\quad=$ Penerapan Model Pembelajaran

Konvensional

$\mathrm{O}_{1}=$ Post- Test Untuk Kelas Eksperimen

$\mathrm{O}_{2}=$ Post- Test Untuk Kelas Kontrol

Prosedur eksperimen ini terdiri dari tiga tahap, yaitu tahap persiapan, pelaksanaan, dan tahap akhir. Adapun uraian dari setiap tahapan tersebut adalah sebagai berikut.

1) Tahap Persiapan

a) Menentukan lokasi penelitian

b) Melakukan observasi lapangan sebelum melakukan penelitian.

c) Menentukan waktu penelitian, kelas penelitian dan materi yang akan diajarkan pada saat melakukan penelitian.

d) Mengadakan validasi terhadap instrumen penelitian mengenai hasil belajar keamanan pangan

2) Pelaksanaan Eksperimen

Pada tahap pelaksanaan eksperimen, kegiatan yang dilakukan adalah melaksanakan kegiatan pembelajaran sesuai dengan RPP (Rencana Pelaksanaan Pembelajran).

3) Tahap Akhir Eksperimen Pada tahap ahir eksperimen, kegiatan yang dilakukan antara lain:

a) Melakukan proses penskoran terhadap lembar jawaban siswa

b) Menghitung skor rata-rata dari tes akhir (posttest) yang diperoleh oleh siswa.

c) Menganalisis data dan menarik kesimpulan dari hasil penelitian yang dilakukan dengan menggunakan teknik analisis data.

d) Penyusunan laporan

Populasi penelitian yang digunakan adalah kelas $X$ Jasa Boga di SMK Pariwisata Triatmajaya Singaraja pada semester genap tahun ajaran $2017 / 2018$ yang terbagi menjadi tiga kelas yaitu X JB 1, X JB 2, X JB 3. Jumlah anggota populasi pada masing-masing kelas disajikan pada Tabel.

Tabel 3

Jumlah Anggota Populasi di Setiap Kelas

\begin{tabular}{ccc}
\hline No & Kelas Populasi & Jumlah Siswa \\
\hline 1. & X JB 1 & 32 orang \\
2. & X JB 2 & 32 orang \\
3. & X JB 3 & 31 orang \\
& Total Populasi & 95 Orang \\
\hline
\end{tabular}

Sampel adalah sebagian dari jumlah dan karakteristik yang dimiliki oleh populasi tersebut (Sugiyono, 2007:56). Sampel penelitian ini dipilih dengan menggunakan teknik random sampling. Dengan teknik random sampling yang 
dipilih bukan individu - individu melainkan kelas yang sudah terbentuk di sekolah dengan cara dilotre. Setiap kelas memiliki kesempatan yang sama untuk menjadi sampel penelitian. Instrumen merupakan alat yang digunakan dalam pengambilan data. "instrumen penelitian adalah alat atau fasilitas yang digunakan oleh peneliti dalam mengumpulkan data agar pekerjaannya lebih mudah dan hasilnya baik, dalam arti lebih cermat, lengkap dan sistematis sehingga lebih mudah diolah, Arikunto (2015 : 136). Dalam penelitian ini, instrumen yang digunakan adalah tes objektif bentuk pilihan ganda.

Valid berarti instrumen tersebut dapat digunakan untuk mengukur apa yang seharusnya diukur (Sugiyono, 2015:177). Sebuah tes dikatakan valid apabila tes tersebut dapat mengukur dan mampu menyikap objek yang hendak diukur (ketepatan alat ukur dengan hal yang diukur) (Agung, 2011:53). Untuk menguji validitas tes, dapat dilakukan validitas isi dan kontruk.

Uji pakar atau ahli digunakan untuk mengetahui validitas isi instrumen yang menyangkut tentang isi atau materi dan format penulisan. Isi dan format instrumen harus konsisten dengan indikator kemampuan pemecahan masalah matematika dan materi atau pelajaran yang akan diukur.

Gregory mengembangkan teknik dalam pengujian validitas isi yang sudah dikuantitatifkan. Mekanisme pengujian validitas isi menurut Gregory adalah sebagai berikut.

1). Para pakar yang dipercaya menilai instrumen melakukan penilaian instrumen perbutir, dengan menggunakan skala. Misalnya skala 12-3-4. Dalam uji validitas isi teh hasil belajar pakar 1 di uji oleh $\mathrm{Ni}$ Made Sugiahtini,S.Pd., M.Pd selaku pengampu mata ajar keamnan pangan di SMK 2 Singaraja dan untuk uji valididitas isi tes hasil belajar pakar 2 di oji oleh $\mathrm{Ni}$ Komang Feggi April Riastini, S.Pd selaku pengampu mata ajar keamanan pangan di SMK Pariwisata Triatma Jaya Singaraja.

2). Pengelompokkan skala, skor 1-2 dikelompokkan kedalam kurang relevan dan skor 3-4 dikelompokkan menjadi sangat relevan.

3). Hasil penilaian para pakar ditabulasi silang.

Untuk mengukur validitas butir tes digunakan rumus korelasi point biserial. Rumus ini digunakan karena jenis tes yang digunakan pada penelitian ini bersifat dikotomi. Dengan taraf signifikansi sebesar $5 \%$ maka dapat diputuskan valid atau tidaknya suatu instrumen dengan membandingkan nilai $r_{\text {hitung }}$ dengan $r_{\text {tabel. }}$ Jika $r_{\text {hitung }}>r_{\text {tabel }}$ berarti valid dan jika $r_{\text {hitung }}$ $\leq r_{\text {tabel }}$ berarti tidak valid.

Uji reliabilitas dilakukan terhadap butir soal yang valid saja, dengan demikian uji reliabilitas bisa dilakukan setelah dilakukan uji validitas. Skor yang diperoleh dari tes kompetensi pengetahuan Keamanan Pangan siswa berupa dikotomi dan heterogen sehingga rumus yang digunakan untuk menentukan reliabilitas tes adalah formula Kuder Richadson 20 (KR-20).

Berdasarkan respon yang diberikan oleh kedua pakar dalam uji validitas isi tes hasil belajar yaitu oleh $\mathrm{Ni}$ Made Sugiahtini,S.Pd., M.Pd selaku pengampu mata ajar keamnan pangan di SMK 2 Singaraja dan Ni Komang Feggi April Riastini, S.Pd selaku pengampu mata ajar keamanan pangan di SMK Pariwisata Triatma Jaya Singaraja. Dapat dihitung validitas isinya. Selanjutnya uji validitas isi menggunakan rumus Greogory.

Berdasarkan hasil analisis validitas tes hasil belajar siswa yang diuji cobakan kepada 35 siswa kelas X Jasa Boga SMK Pariwisata Triatma Jaya Singaraja didapatkan 29 butir tes yang dinyatakan valid dan 1 butir soal dinyatakan tes invalid dan 30 soal diuji cobakan.

Pengujian validasi dengan menggunakan microsoft excel kreterianya adalah item butir soal dinyatakan valid apabila $r$ hitung $>r$ tabel yang digunakan adalah 35 siswa maka $r$ tabel yang digunakan adalah 0,334

Reliabilitas berhubungan dengan masalah kepercayaan. Suatu tes dapat dikatakan mempunyai taraf kepercayaan yang tinggi jika tes tersebut dapat memberikan hasil yang tetap. Maka 
pengertian reliabilitas tes berhubungan dengan masalah ketetapan hasil tes. Dalam kaitan dengan instrumen atau tes penelitian, reliabilitas itu merujuk pada konsistensi skor, artinya kemampuan suatu instrumen atau tes untuk menghasilkan skor yang mendekati sama dari setiap individu apabila dilakukan pengujian ulang atau terhadap individu atau testee lain yang berbeda.

Uji reliabilitas dilakukan terhadap butir soal yang valid saja, dengan demikian uji reliabilitas bisa dilakukan setelah dilakukan uji validitas. Skor yang diperoleh dari tes hasil belajar tata hidang berupa dikotomi dan heterogen sehingga rumus yang digunakan untuk menentukan reliabilitas tes adalah formula Kuder Richadson 20 (KR-20)

Dalam pemberian interpretasi terhadap koefesien reliabilitas tes $r_{11}$ pada umumnya digunakan patokan sebagai berikut: (1) Apabila $r_{11} \geq 0,70$ berarti tes hasil belajar yang sedang diuji realibilitasnya dinyatakan telah memiliki reliabilitas yang tinggi (reliable), (2) Apabila $r_{11}<0,70$ berarti tes hasil belajar yang sedang diuji realibilitasnya dinyatakan belum memiliki reliabilitas yang tinggi (unreliable).

Berdasarkan hasil analisis reliabilitas test hasil belajar siswa dengan menggunakan rumus KR-20, didapatkan angka realibilitas sebesar 0,80 dengan butir item soal sebanyak 28 butir dan berkualifikasi sangat tinggi. Jadi dapat disimpukan bahwa instrument tersebut layak dan dapat dipercaya untuk digunakan sebagai alat pengumpulan data

Penelitian ini bertujuan untuk mengetahui perbedaan hasil belajar antara siswa yang diberi perlakuan dengan model pembelajaran STAD (Student Team Achievement Division) berbantuan LKS dengan siswa yang di beri perlakuan dengan menggunakan model pembelajaran konvensional. Analisis data pada penelitian ini menggunakan uji $\mathrm{t}$ ( $t$ test). Untuk analisisnya menggunakan teknik pengujian statistik deskriptif dan juga menggunakan uji persyaratan analisis.

Analisis deskriptif digunakan untuk mengetahui tinggi rendahnya kualitas dari hasil belajar siswa, baik yang diajar dengan STAD (Student Team Achievement Division)berbantuan LKS maupun yang menggunakan model pembelajaran konvensional.

Standar deviasi (s) adalah suatu ukuran persebaran atau disperse skorskor. Untuk menjelaskan homogenitas kelompok digunakan teknik varians (Sugiyono, 2012:56). Varians adalah suatu angka yang menunjukkan ukuran variabilitas yang dihitung dengan jalan mengkuadratkan standar deviasi.

Analisis varian berfungsi untuk mengkaji varian-varian penelitian. Adapun analisis varian yang dilakukan adalah uji normalitas data, uji homogenitas data, dan uji hipotesis. Uji normalitas dan uji homogenitas data dilakukan terlebih dahulu sebagai uji prasyarat untuk dapat melakukan uji selanjutnya yaitu uji hipotesis.

Uji normalitas penting dilakukan untuk mengetahui normal tidaknya data yang diperoleh. Untuk menguji normalitas digunakan $U j i$ Liliefors pada taraf signifikansi $5 \%$. Pada pengujian normalitas data dengan Uji Liliefors dicari selisih frekuensi sebaran data $(F(Z))$ dengan frekuensi kumulatif sampai dengan batas tiap-tiap data $(S(Z))$.

Uji homogenitas varians dilakukan untuk mencari tingkat kehomogenan secara dua pihak yang diambil dari kelompok-kelompok terpisah dari satu populasi yaitu kelompok kontrol dan kelompok eksperimen. Uji homogenitas varians untuk dua kelompok digunakan uji F. Kriteria pengujian jika $F_{\text {hitung }}>F_{\text {tabel }}$ maka sampel tidak homogen dan jika $F_{\text {hitung }}<F_{\text {tabel }}$ maka sampel homogen. Pengujian dilakukan dengan taraf signfikansi $5 \%$ dengan derajat kebebasan untuk pembilang $n_{1}-1$ dan derajat kebebasan untuk penyebut $n_{2-1}$.

Uji hipotesis yang dilakukan dalam penelitian ini menggunakan analisis uji-t karena penelitian ini merupakan penelitian yang membandingkan 1 variabel bebas dan variable terikat.

Uji hipotesis yang dilakukan dalam penelitian ini menggunakan analisis uji-t karena penelitian ini merupakan penelitian yang membandingkan 1 variabel bebas dan variable terikat. Hipotesis statistik 
Jurnal Bosaparis: Pendidikan Kesejahteraan Keluarga

Volume 10, Nomor 1, Maret 2019

yang diajukan dan akan diuji dalam penelitian ini adalah sebagai berikut:

$$
\begin{aligned}
& \mathrm{H}_{0}: \mu_{1}=\mu_{2} \\
& \mathrm{H}_{1}: \mu_{1 \neq} \mu_{2}
\end{aligned}
$$

Keterangan :

$\mathrm{H}_{0} \quad=$ Hipotesis Awal

$\mathrm{H}_{1}=$ hipotesis alternatife

$\mu_{1}=$ rata-rata hasil belajar siswa dengan model pembelajaran STAD (Student Team Achievement Divisions) berbantuan LKS

$\mu_{2} \quad=$ rata-rata hasil belajar siswa dengan model pembelajaran konvensional Teknik analisis data yang digunakan untuk menguji hipotesis dari penelitian ini adalah menggunakan uji-t independen untuk menguji hasil post-test kelompok eksperimen dan kelompok kontrol. Uji-t untuk sampel yang tidak berkorelasi atau terpisah terdari dua jenis rumus yaitu separated varian dan polled varians.

Hipotesis jawaban teoritik dan dianggap paling tinggi tingkat kebenarannya terhadap permasalahan atau pertanyaan penelitian. Jawaban teoritik ini perlu diuji kebenarannya secara empiris melalui data penelitian. Menurut Agung, (2015 : 10) menyatakan bahwa "hipotesis berarti simpulan atau jawaban sementara yang kebenarannya harus dibuktikan (uji) dengan data empiris di lapangan)

Pengujian hipotesis tersebut dijabarkan kembali menjadi $\mathrm{H}_{0}$ dan $\mathrm{H}_{1}$ sebagai berikut.

$\mathrm{H}_{0}$ : tidak terdapat perbedaan hasil belajar Keamanan Pangan pada siswa kelas $X$ SMK Pariwisata Triatma Jaya Singaraja antara siswa yang belajar menggunakan model pembelajaran STAD berbantuan LKS dan siswa yang menggunakan model pembelajaran konvensional, melawan.

$\mathrm{H} 1$ : terdapat perbedaan hasil belajar Keamanan Pangan pada siswa kelas X SMK Pariwisata Triatma Jaya Singaraja antara siswa yang belajar menggunakan model pembelajaran STAD berbantuan LKS dan siswa yang menggunakan model pembelajaran konvensional.

\section{HASIL DAN PEMBAHASAN}

Penelitian ini merupakan penelitian dengan rancangan non equivalen control group design yang melibatkan dua kelompok sampel yaitu kelompok eksperimen dan kelompok kontrol. Pada kelompok eksperimen dibelajarkan dengan model pembelajaran (STAD) Student Team Achievemnt Divisionsl berbantuan LKS dan pada kelompok kontrol tidak dibelajarkan dengan model pembelajaran (STAD) Student Team Achievemnt Divisions berbantuan LKS.

Deksripsi data dalam hasil penelitian ini memaparkan tentang nilai rata-rata (mean), standar deviasi, varian, nilai minimum dan nilai maksimum berdasarkan data hasil belajar keamanan pangan kelompok eksperimen dan kelompok control yang dikerjakan dengan SPSS 23.

Tabel 4

Deskripsi Data Hasil Belajar Siswa

\begin{tabular}{cccccc}
\hline Kelas & Mean & $\begin{array}{c}\text { Sts. } \\
\text { Deviasi }\end{array}$ & Varian & Min & Mak \\
\hline Eksperimen & 84.19 & 7.427 & 55.16 & 75 & 95 \\
& & & & & \\
Kontrol & 76.09 & 4.353 & 18.53 & 70 & 85 \\
\hline
\end{tabular}

Berdasarkan data di atas dapat dikatakan bahwa nilai rata-rata kelas eksperimen lebih besar dibandingkan dengan kelas kontrol.

Pengujian asumsi yang dilakukan pada penelitian ini meliputi uji normalitas, sebaran data uji homogenitas varian hasil post test kelompok eksperimen dan kelompok kontrol.

Uji normalitas dimaksudkan untuk mengetahui apakah sebaran data skor hasil belajar keamanan pangan siswa masing-masing kelompok berdistribusi normal atau tidak sehingga dapat menentukan teknik analisis datanya. Uji normalitas sebaran data dalam penelitian ini menggunakan SPSS 23 dengan rumus Lilliefors. 
Jurnal Bosaparis: Pendidikan Kesejahteraan Keluarga

Volume 10, Nomor 1, Maret 2019

Tabel 5

Hasil output test of normality

Tests of Normality

\begin{tabular}{lrccrcc}
\hline & \multicolumn{3}{c}{$\begin{array}{c}\text { Kolmogorov- } \\
\text { Smirnov }\end{array}$} & \multicolumn{3}{c}{ Shapiro-Wilk } \\
\cline { 2 - 7 } & Statistic & df & Sig. & Statistic & df & Sig. \\
\hline $\begin{array}{l}\text { kelas } \\
\text { ekprimen }\end{array}$ & .165 & 31 & .030 & .876 & 31 & .002 \\
kelas & .212 & 32 & .001 & .896 & 32 & .006 \\
kontrol & .21 & & & & & \\
\hline
\end{tabular}

a. Lilliefors Significance Correction

Berdasarkan output test of normality, diperoleh nilai signifikansi untuk kelas eksperimen sebesar 0,030, sedangkan kelompok kontrol sebesar 0,000 . Karena nilai signifikansi kelas eksperimen dan kelas kontrol lebih rendah 0,05 , maka dapat disimpulkan bahwa data hasil belajar berdistribusi normal.

Uji homogenitas varian untuk kedua kelompok digunakan uji $F$. Berdasarkan hasil pengujian homogenitas varian data kelompok eksperimen dan kelompok kontrol $F_{\text {hitung }}=2,97<F_{\text {tabel }}=$ 4,00 maka sampel homogen. Pengujian dilakukan dengan taraf signifikansi 5\% dengan derajat kebebasan untuk pembilang $n_{1}-1$ dan derajat kebebasan untuk penyebut $n_{2}-1$.

Berdasarkan hasil pengujian normalitas dan homogenitas, maka diperoleh bahwa data yang didapatkan dari kelompok eksperimen dan kelompok kontrol berdistribusi normal dan homogen. Berdasarkan data tersebut, maka dilakukan uji hipotesis dengan menggunakan rumus polled varians, kriteria pengujian adalah $\mathrm{H}_{0}$ ditolak jika $t_{\text {hitung }}>t_{\text {tabel }}$ dengan $\mathrm{db}=\left(n_{1}+n_{2}-2\right)$.

Dalam hasil uji hipotesis dengan menggunakan Ms.Excel didapat 5,442 > 1,679 dan menggunakan SPSS 23 didapat $0,000<0,05$. Hasil ini menunjukan bahwa $\mathrm{H}_{0}$ berada pada daerah penolakan, maka diputuskan bahwa $\mathrm{H}_{0}$ ditolak. Jadi terbukti bahwa Terdapat pengaruh yang signifikan dalam penerapan model pembelajaran STAD (Student Team Achievement Division) berbantuan LKS terhadap hasil belajar siswa kelas $X$ jasa boga di SMK Pariwisata Triatma Jaya Singaraja yaitu nilai hasil belajar siswa kelompok eksperimen lebih tinggi dibandingkan dengan nilai hasil belajar kelompok kontrol.

Pembahasan hasil-hasil penelitian dan pengujian hipotesis menyangkut tentang kemampuan menyelesaikan soal keamanan pangan siswa khususnya pada materi Mikroorganisme Pengotor .

Berdasarkan hasil penelitian diketahui bahwa terdapat perbedaan hasil belajar keamanan pangan antara siswa yang mengikuti model pembelajaran STAD (Student Team Achievement Divisions) berbantuan LKS dengan siswa yang tidak menggunakan model pembelajaran STAD (Student Team Achievement Divisions) berbantuan LKS pada siswa kelas $X$ SMK Pariwisata Triatma Jaya Singaraja. Tinjauan ini didasarkan pada rata-rata hasil belajar keamanan pangan. Rata-rata nilai hasil belajar keamanan pangan siswa kelompok eksperimen berada pada kategori sangat tinggi, sedangkan nilai hasil belajar keamanan pangan siswa kelompok kontrol berada pada kategori rata-rata.

Keadaan tersebut dikarenakan dalam proses pembelajaran STAD (Student Team Achievement Divisions) berbantuan LKS mampu menciptakan suatu lingkungan belajar yang efektif, dengan sistem beajar berkelompok yang terbagi dalam kelompok hiterogen dan pemberian penghargaan yang dapat menciptakan motivasi dan semangat siswa didalam kelompok untuk bekerja sama mengerjakan LKS dan melaksanakan presentasi dengan baik. Selain itu suasana serta lingkungan belajarnya melalui interaksi yang terjadi di dalam kelas serta dapat meningkatkan prestasi siswa. Hal ini sejalan dan sesuai dengan yang disampaikan Kurniasih (2016 : 22) 1) Dalam kelompok siswa dituntut untuk aktif sehingga dengan model ini siswa dengan sendirinya akan percaya diri dan meningkatkan kecakapan individu. 2) Interaksi sosial terbangun dalam kelompok dengan sendirinya siswa belajar dalam bersosialisasi dengan lingkungan kelompok. 3) Dengan kelompok yang ada siswa diajarkan untuk membangun komitmen dalam mengembangkan kelompoknya. 4) Mengajarkan untuk menghargai orang lain 
dan saling percaya. 5) Dalam kelompok siswa diajarkan untuk saling mengerti dengan materi yang ada, sehingga siswa saling memberitahu dan mengurangi sifat kompetitif.

Selanjutnya kelebihan analisis data menggunakan uji-t diketahui $t_{\text {hitung }}=5,36$ dan $t_{\text {tabel }}$ pada taraf signifikansi $5 \%=$ 1,67, sehingga dapat disimpulkan bahwa $\mathrm{H}_{0}$ ditolak dan $\mathrm{H}_{1}$ diterima, sehingga model pembelajaran STAD (Student Team Achievement Divisions) berbantuan LKS berpengaruh secara signifikan terhadap hasil belajar keamanan pangan siswa kelas X SMK Pariwisata Triatma Jaya Singaraja yaitu nilai hasil belajar siswa kelompok eksperimen lebih tinggi dibandingkan nilai hasil belajar siswa kelompok eksperimen lebih tinggi dibandingkan nilai hasil belajar siswa kelompok kontrol.

$$
\text { Dengam adanya model }
$$

pembelajaran STAD (Student Team Achievement Divisions) berbantuan LKS siswa menjadi lebih aktif dikelas karena siswa dituntut bekerjasama dengan baik dalam mengerjakan LKS yang sudah disiapkan oleh guru dengan demikian siswa siswa merasa termotivasi dan bersemangat untuk mingkatkan nilai kelompok. Hasil penelitian ini didukung dengan penelitian Sudiarpa yang melakukan penelitian tahun 2015, memperoleh hasil bahwa terdapat perbedaan hasil belajar IPA yang signifikan antara siswa yang mengikuti pembelajaran dengan model pembelajaran kooperatif STAD dengan siswa yang mengikuti pembelajaran dengan model pembelajaran konvensional.

\section{SIMPULAN DAN SARAN}

Kesimpulan berdasarkan hasil penelitian dan pembahasan pada penelitian eksperimen kelas yaitu adanya pengaruh yang signifikan dalam penerapan model pembelajaran STAD (Student Team Achivement Divisions) berbantuan LKS terhadap hasil belajar Keamanan Pangan di kelas $X$ SMK Pariwisata Triatma Jaya Singaraja. (2tailed) sebesar 0,000 $<0,05$, dan t-hitung $=5,36$, sehingga dapat disimpilkan bahwa $\mathrm{H}_{0}$ ditolak dan $\mathrm{H}_{1}$ diterima, sehingga model pembelajaran STAD (Student Team Achievement Divisions) berbantuan LKS berpengaruh secara signifikan terhadap hasil belajar Keamanan Pangan di kelas $X$ SMK Pariwisata Triatma Jaya Singaraja Tahun Pelajaran 2018/2019. Yaitu nilai hasil belajar siswa kelompok eksperimen lebih tinggi dibandingkan nilai hasil belajar siswa kelompok kontrol.

Saran yang dapat disampaikan berdasarkan penelitian yang telah dilakukan adalah sebagai berikut. (1) Kepada siswa di sekolah dasar dalam mengikuti proses pembelajaran agar selalu terlibat aktif sehingga dapat meningkatkan hasil belajar dan mendapatkan pengetahuan melalui pengalaman yang ditemukan sendiri. (2) Kepada guru yang menemukan permasalahan yang sama dengan penelitian ini khususnya dalam proses pembelajaran Keamanan Pangan agar menggunakan model pembelajaran STAD (Student Team Achievement Divisions) berbantuan LKS untuk meningkatkan hasil belajar keamanan pangan siswa. (3) Kepada kepala sekolah, khususnya SMK agar menjadikan penelitian ini emnjadi salah satu pedoman dalam mengambil kebijakan-kebijakan yang dibuat dalam usaha meningkatkan kualitas pembelajaran di sekolah. (4) Bagi peneliti lain yang berminat untuk mengadakan penelitian lebih lanjut tentang model pembelajaran STAD (Student Team Achievement Divisions) berbantuan LKS dam bidang mata pelajaran Keamanan Pangan maupun dengan variabel yang berbeda agar mengguanakan penelitian ini sebgai referensi dan acuan kepustakaan agar bisa membuat penelitian yang lebih baik lagi.

\section{DAFTAR PUSTAKA}

Agung, A.A Gede. 2011. Pengantar Evaluasi Pendidikan. Singaraja: Universitas Pendidikan Ganesha

Arikunto, Suharsimi. 2015. Dasar-Dasar Evaluasi Pendidikan (Edisi 2). Jakarta: Bumi Aksara 
Jurnal Bosaparis: Pendidikan Kesejahteraan Keluarga

Volume 10, Nomor 1, Maret 2019

Koyan. 2012. Statistik : Pendidikan Teknik Analisis Data Kuantitatif. Singaraja : Universitas Pendidikan Ganesha

Kurniasih, Imas. 2016. Ragam Pengembangan Model Pembelajaran Untuk Peningkatan Profesioanlitas Guru. Jakarta: Kata pena

Sugiyono.2015. Metode Penelitian Kuantitatif, Kualitatif dan R\&D, Bandung: Alfabeta.

Yasir. 2015. "Pengaruh Model Pembelajaran STAD Terhadap Hasil Belajar Mata Pelajaran Akuntansi". Reserch and DevelopmentnJurnal Of Education. Volume 2 